\title{
NATURAL SUSTAINABILITY OF TODDY PALM (Borassus flabellifer L.) IN LINAMNUTU, TIMOR TENGAH SELATAN, NUSA TENGGARA TIMUR (Sustainabilitas alami Lontar (Borassus flabellifer L.) di Desa Linamnutu, Timor Tengah Selatan, Nusa Tenggara Timur)
}

\author{
Retno Peni Sancayaningsih" ${ }^{1 *}$, Sigit Heru Murti Budi Santosa ${ }^{2}$ dan Asri Vidya Utami ${ }^{3}$ \\ ${ }^{1}$ Laboratory of Ecology and Conservation, Faculty of Biology, Gadjah Mada University, \\ Jl. Teknika Selatan, Sekip Utara, Yogyakarta 55281. \\ ${ }^{2}$ Faculty of Geography, Gadjah Mada University, Sekip Utara, Yogyakarta 55281. \\ ${ }^{3}$ Faculty of Biology, Gadjah Mada University, Jl. Teknika Selatan, Sekip Utara, Yogyakarta 55281. \\ *Penulis korespondensi. Tel/fax: +62-274-580839. Email: retpeni@ugm.ac.id.
}

Diterima: 6 Juni 2014

Disetujui: 22 April 2015

\begin{abstract}
Borassus flabellifer usually known as Toddy palm or Lontar is a member of family Arecaceae, a kind of palms that highly distributed in Nusa Tenggara Timur Province. This palm is abundant and wellknown for its endless uses, such as for building material, cattle feed, and food for the people in Linamnutu. Therefore study on Toddy palm density, fertility, and its survivorship is necessary to reveal natural sustainability of Toddy Palm for future use. This study was done through field work in Linamnutu Village, Timor Tengah Selatan Regency, Nusa Tenggara Timur Province from June $19^{\text {th }}$ to July $1^{\text {st }}$ 2011. Six sampling sites were selected based on ALOS AVNIR-1 analyzed using ArcGIS 9.3 and ENVI 4.5. Results showed that density of Lontar in nature was 195 trees per hectare, while using remote sensing methods plant density was 221 trees per hectare in 4,332 hectare. Total lontar trees in the village are 845.885 trees. Seed survivorship is $0.34 \%$. The high density and number of trees in more than 50 \% cover area is still enough for future needs of inhabitants in Linamnutu, even though for future economic subsistence, a local wisdom to culture Lontar seedlings was encouraged for the future prospect.
\end{abstract}

Keywords: Linamnutu, lontar, seed survivorship, sustainability, Toddy palm.

\begin{abstract}
Abstrak
Borassus flabellifer yang dikenal sebagai Lontar (Toddy palm) adalah anggota famili Arecaceae, merupakan tumbuhan palma yang tersebar sangat baik di Propinsi Nusa Tenggara Timur. Tumbuhan palma ini sangat melimpah dan dikenal karena kegunaannya yang sangat tinggi, materi bahan bangunan, makanan ternak, dan juga sebagai makanan untuk penduduk di desa Linamnutu. Oleh karena itu penelitian tentang sustainabilitas alami, meliputi kerapatan tumbuhan, fertilitas dan nilai sintasannya sangat penting dikethaui untuk penggunaan di masa mendatang. Penelitian densitas Lontar ini dilaksanakan di desa Linamnutu, kecamatan Timor Tengah Selatan, NTT pada tanggal 19 Juni sampai dengan 1 Juli 2011 dari 6 lokasi yang dipilih menggunakan analisis citra ALOS AVNIR-2 yang diolah dengan software ArcGIS 9.3 dan ENVI 4.5. Hasil penelitian menunjukkan bahwa kerapatan Lontar di alam sebesar 195/ha, sementara menggunakan pendekatan NDVI diperoleh kerapatan 221/ha dengan luas wilayah 4.332 ha. Jumlah total pohon Lontar di desa Linamnutu adalah 845.885 buah dengan sintasan biji sebesar 0,34 \%. Kerapatan pohon yang masih tinggi di lebih dari 50\% luas wilayah masih memenuhi keperluan bahan bangunan di masa mendatang bagi penduduk desa Linamnutu. Meskipun demikian, untuk pemenuhan ekonomi keluarga secara swasembada, pemencaran semai Lontar untuk dibudidayakan perlu didorong untuk prospek yang lebih baik di masa mendatang.
\end{abstract}

Kata kunci: Linamnutu, lontar, sintasan biji, sustainabilitas, Toddy palm.

\section{INTRODUCTION}

Toddy Palm (Borassus flabellifer L.) or so called Lontar, is an important local plant that supports villages life (brown sugar and building) (Jayusman, 2010). Local people in Linamnutu village mostly farmers, their local culture of self sufficiency is still being practiced in their daily consumption. Production concept of farmers both in agriculture and in horticulture is still in traditional way, this means they produce staple food that enough to cover their daily needs, they don't think production for infestation for the future. Based on this reality, management of Lontar orchard for brown sugar production is still far from business practices, such as seedling preparation that still depend on its natural fecundity, no fertilizer inputs, and there is no effort to improve their process in order to get better financial benefit. When population of the village increases, the needs for food and housing also increase, therefore ecological 
study of Lontar, its natural fecundity has been studied.

Toddy palm (Fig 1) is one of family member of Arecaceae that grows in semi arid to humid area. This palm can grow about $15-30 \mathrm{~m}$ tall, with the average stem diameter of $60 \mathrm{~cm}$. This plant is dioecious (it separates between male and female plants), with fruits are arranged in a stem of about 20 fruits in each stem (Morton, 1988). This palm originally came from Africa and its distribution spreads from India, Malaysia, Cambodia, and Indonesia (East Java, East Nusa Tenggara and South Sulawesi) (Ayarkwa, 1997; Anonymous, 2011).
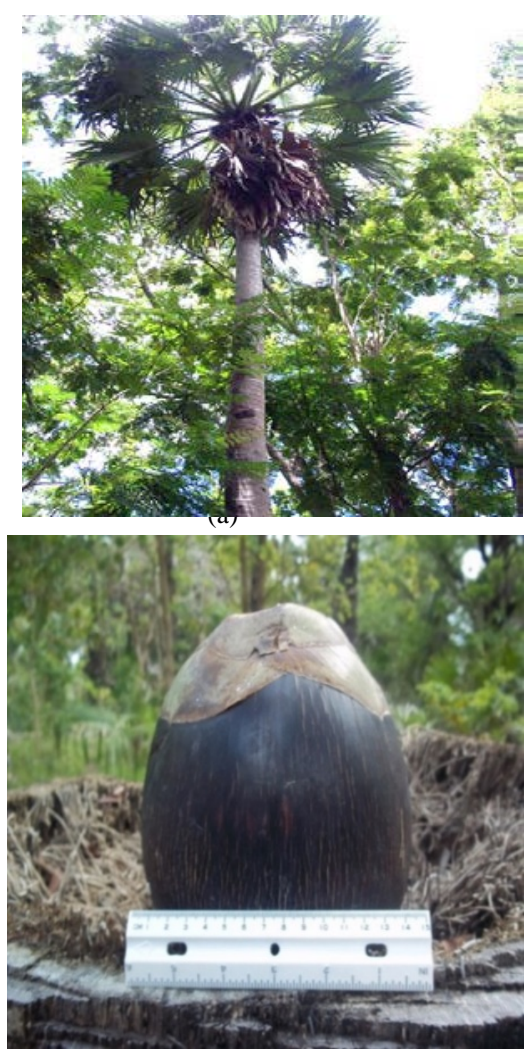

(c)
Lontar leaves are greyish green color, fan shape, stiff, with diameter about $150 \mathrm{~cm}$, and sticks out like finger. Leave petiole is $100 \mathrm{~cm}$ long, and each leaf has short leaf midrib, with spiny structure at its petiole's site. Lontar trees become mature from 12 to 20 years, and it lives up to 150 years, with mostly its age is about 80 years (Anonymous, 2011). Male flowers are always branching, while female flowers usually are not branching, with number of flowers about 20 - 30 hanging down from its stem, brown to dark brown color. Female flowers are
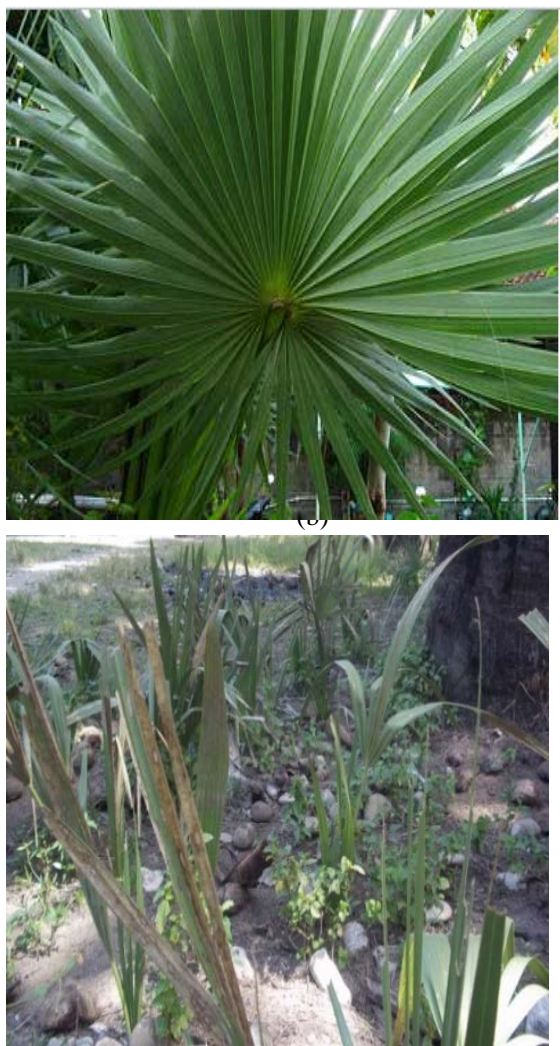

(d)

Fig 1. (a) Lontar tree, (b) Lontar leaves, (c) Lontar fruit, (d) Lontar seedling.

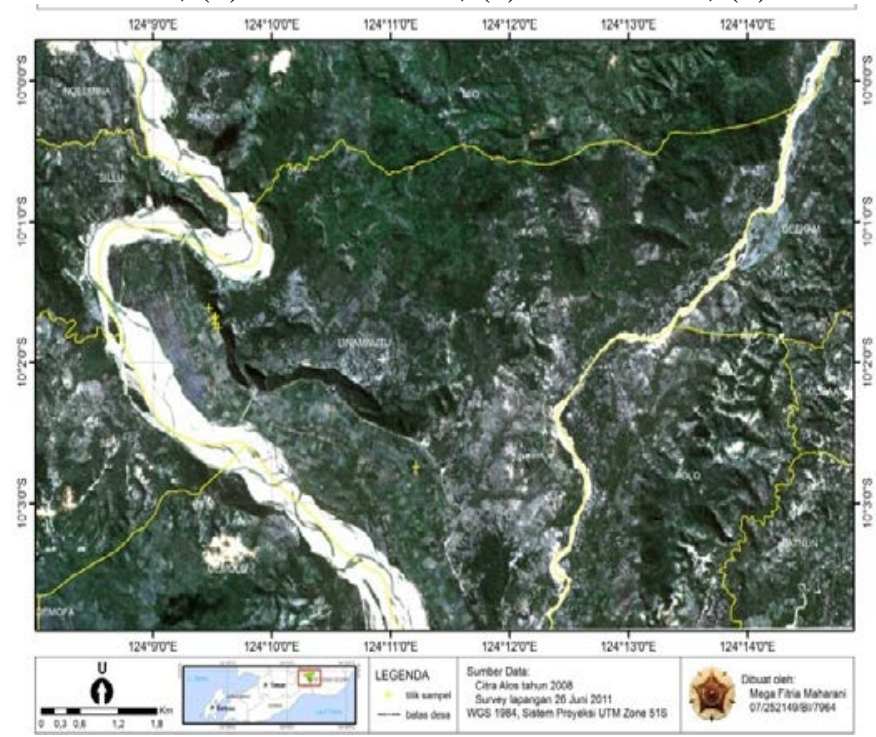

Fig 2. Alos imagery of Linamnutu village in Timor Tengah Selatan, NTT. 
white, groupped in a stem flower with a flower stalk of $50 \mathrm{~cm}$ long. Lontar is iteroparous or pleonanthic plant, that can produces fruits many times in its whole life (flowering 2-3 times in a year). Number of fruits ranges from 20-25 in its stem, with diameter between 7-20 cm (Bayton, 2007; Anonymous, 2011).

Since Lontar is vegetation that fit to grow in the dry habitat in Timor and this is one of two species whom Linamnutu inhabitants relied on for daily uses, with very low effort in cultivation, therefore study to reveal its natural sustainability (density, reproductive status, and seed survivorship) is very important

\section{EXPERIMENTAL METHOD}

\section{Study sites}

The field work of the research had been conducted from $19^{\text {th }}$ June-to $1^{\text {st }}$ July 2011. Linamnutu village is located in South Amanuban Sub regency, Timor Tengah Selatan Regency, Nusa Tenggara Timur (NTT). Linamnutu village is one out of 14 villages in Amanuban Selatan sub regency, located in coordinates of $\mathrm{N} 8889341,17580$, and S 629273,91361 . It is located in valley of Noelmina watershed, South East Timor, NTT. Linamnutu village map can be seen in Fig 2. Area of Linamnutu is $42.823 \mathrm{~km}^{2}$, with the surrounding boundary of Mio, Seki, Sillu and Oeekam villages (Myers et al., 2010).

Linamnutu village consists of 3 sub-villages, those are: Oetaman, Hausunaf, and Linamnutu. Geografically these 3 sub-villages (Dusun) are separated from the other sub-villages. In total it has more than 9 RW dan 20 RT (Myers et al., 2010).

\section{Sampling and vegetation analysis}

Six sampling sites were selected from ALOS images of Linamnutu village 2008 and on site considerations. These study sites represent study areas from the high up to low land in terms of geomorphology, represented the whole Lontar orchad areas with coordinates of those sampling sites are presented in Table 1.

Six quadrat sampling plots of $30 \times 30 \mathrm{~m}^{2}$ size of each study sites were measured both trees and seedling densities, and tree stem diameter to estimate

Table 1. Coordinate of sampling sites.

\begin{tabular}{ccc}
\hline Plot No & East & North \\
\hline Plot1 & 629163 & 8889231 \\
Plot2 & 629391 & 8888869 \\
Plot3 & 629590 & 8888505 \\
Plot4 & 630058 & 8889274 \\
Plot5 & 629040 & 8889469 \\
Plot6 & 629217 & 8889213 \\
\hline
\end{tabular}

its age was measured at Diameter Breast Height (DBH) (Subagja, et al. 2009). Total count methods were used in seedling density within the study sites to predict its natural reproduction. Male and female plants in this areas were reccorded and detected from their flowers or its leave-scar spiral type.

\section{Trees density estimation using GIS}

Spectral values of ALOS AVNIR-2 imagery with $10 \mathrm{~m}$ spatial resolution were analysed to estimate trees density using ArcGIS 9.3 and ENVI 4.5. To differentiate Lontar population, supervised grouping with maximum likelihood model was used (Sudiana and Diasmara, 2008).

Tree density estimation of an image analysis was represented by vegetation index values, using Normalized Difference Vegetation Index (NDVI) (Danoedoro, 1996), with the NDVI formulation as follows:

$$
N D V I=\frac{\text { near infrared band }- \text { red band }}{\text { near infrared band }+ \text { red band }}
$$

NDVI values between 0 to 1 represented vegetation, while NDVI between -1 to 0 represented non-vegetation. The higher this values showed the higher the tree density (Danoedoro, 1996). These NDVI values and ground check measurements were then analysed its relations with the regression analysis.

\section{Calculation of fecundity value}

Fecundity was estimated through seeds survivorship (Tarumingkeng, 1994) calculated from the number of seedlings with various stages (number of open leaflets produced by seedlings) found in the diameter surrounding female plants, and average seeds density surounding the female plants. Lontar fecundity can be deducted from seeds that grow as seedlings underneath female trees. Number of seeds produced was calculated from fallen seeds under each female tree in the $2.5 \mathrm{~m}$ radius away from trees. Average seed density counted using triplicate of 0.5 x $0.5 \mathrm{~m}^{2}$ quadratic plots for each tree of 5 trees in every study site.

\section{RESULTS AND DISCUSSION}

\section{Plant density and its reproductive status}

From the field survey, showed that average density of Lontar was 195 plants/ha with ratio between female to male plants was 0.46 (Table 2). Random measurement of stem diameter of 47 trees and 77 seedlings and their frequency were summarized in Table 3. Stem diameter is one character related to plant ages that can be measured 
Table 2. Field density and vegetation index based on image pixel character (NDVI).

\begin{tabular}{|c|c|c|c|c|c|}
\hline \multirow[t]{2}{*}{ Plot } & \multicolumn{2}{|c|}{ Number of plants } & \multirow[t]{2}{*}{ Total } & \multirow{2}{*}{$\begin{array}{l}\text { Average density } \\
\text { (plants/ha) }\end{array}$} & \multirow{2}{*}{$\begin{array}{c}\text { NDVI } \\
\text { (vegetation index) }\end{array}$} \\
\hline & Male & Female & & & \\
\hline Plot 1 & 7 & 6 & 13 & $541-722(720)$ & 0.088 \\
\hline Plot 2 & 5 & 5 & 10 & $833-1,042(1040)$ & 0.063 \\
\hline Plot 3 & 12 & 5 & 17 & 189 & Outlier \\
\hline Plot 4 & 3 & 3 & 6 & $67(70)$ & 0.115 \\
\hline Plot 5 & 10 & 15 & 25 & $278(280)$ & 0.215 \\
\hline Plot 6 & 6 & 7 & 13 & $144(150)$ & 0.305 \\
\hline \multirow[t]{2}{*}{ Average } & & & 14 & 407 & \\
\hline & & \multicolumn{4}{|c|}{ Ratio between female to total : 0.46} \\
\hline
\end{tabular}

Source : Data analysis.

Table 3. Stem diameter, frequency, and basal area.

\begin{tabular}{ccccc}
\hline Stem circle & Number of tree & Frequency & \multicolumn{2}{c}{ Basal area $\left(\mathrm{cm}^{2}\right)$ of trees } \\
\cline { 4 - 5 }$(\mathrm{cm})$ & and seedling & $(\%)$ & Average & Total \\
\hline$<50 \mathrm{~cm}$ & $5+77=81$ & 71.7 & $1,516.2$ & 7,581 \\
$50-59 \mathrm{~cm}$ & 15 & 13.3 & $2,134.4$ & 32,016 \\
$60-69 \mathrm{~cm}$ & 12 & 10.6 & $3,262.6$ & 39,154 \\
$70-79 \mathrm{~cm}$ & 3 & 2.7 & $4,493.3$ & 13,486 \\
$>80 \mathrm{~cm}$ & 2 & 1.7 & $5,348.0$ & 10,696 \\
\hline
\end{tabular}

Source : Data analysis.

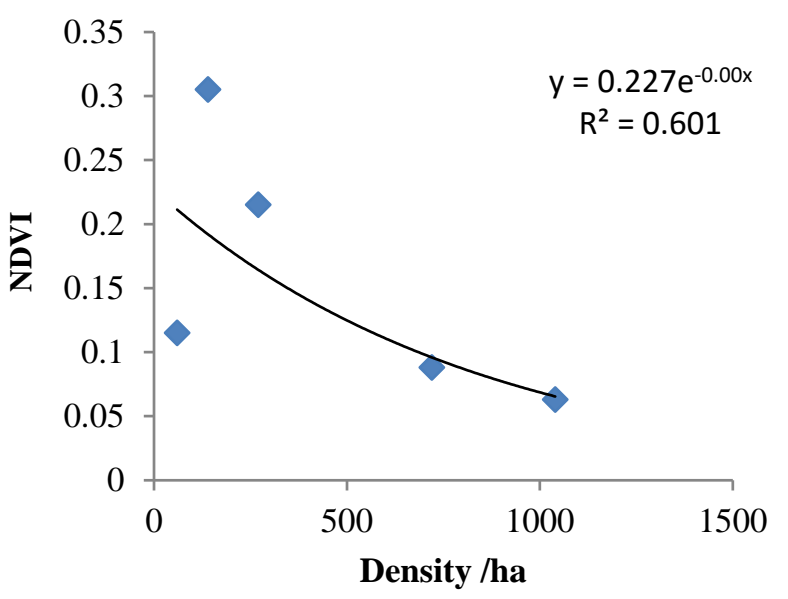

Fig 3. Regression curve between density of $B$. flabellifer L and NDVI.

in the field. This age structure reflected their reproductive status of the plant community (Barbour et al., 1987). Table 3 showed that Lontar plants with stem circle between $50-69 \mathrm{~cm}$ dominated from the field sites, this can be deducted that Lontar tree community in Linamnutu was still sustain as the young trees was in higher proportion (72.2\%) (Table 3).

\section{Plant Population Calculated from NDVI Index}

Based on the plant density value of each sample plot sites, then vegetation index based on image pixel character (NDVI) of each sites were reccorded (Table 2). The regression analysis between plant density and NDVI (Fig 3.) then be used to estimate plant density and elaborate area from the satelite image through ENVI 4.5 software. Based on bandmath calculation using ENVI 4.5 software, estimated tree population from Linamnutu was shown in Table 4. Plant density calculated from software ranged from 12 to 658 trees per hectare. These densities, however was mixture between stand, sapling, and seedling, therefore corection in calculating should be taken (Sudiana and Diasmara, 2008; Sigit, personal comm.). Assuming that maximum tree density as a stand in one hectare is 256 trees, therefore bandmath value above 256 was corrected only 256 trees/ha (Table 4).

Regression analysis between tree density and NDVI values resulted regression function of $y=$ $0.227 \mathrm{e}^{-0.001 \mathrm{x}}$ with determinant coefisient of $\mathrm{R}^{2}=$ 0,602 (Fig. 3). Estimated average tree density of Lontar calculated with software was 221 trees/ha. Trees density measured from the field sites showed that the real tree density of 195 trees/ha was lower than that of an estimated tree density (221 trees/ha) calculated using remote sensing method. This may happen due to that NDVI value was an estimation index that in regression function may not perform linearly, therefore scientific judgement to take correction factor as one consideration. Secondly, regression function formed in this case had coefficient of confidence of $\mathrm{R}^{2}=0,602$, and thirdly, NDVI value produced from the computer image pixel that cannot differentiate between Lontar and Gewang (Corypha utan, Lamk.), similar canopy images between two species that grew in the same habitat might reflected as the same object (Sancayaningsih et al., 2012).

Tree density classification and estimated cover area dominated by Lontar trees in Linamnutu village 
was presented in Table 5. It shows that 4332.05 ha and $18 \%$ of the whole area in Linamnutu was dominated with Lontar tree. Among these, $47 \%$ of this area is in the category of very dense (Table 5). Therefore the potency of Lontar was still good with the total number of Lontar was 845,885 trees in Linamnutu (Table 4).

\section{Survivorship of Lontar Seeds}

Lontar survivorship can be deducted from seeds that grow as seedlings underneath female trees. Number of seeds was calculated from each female tree in the radius of $2.5 \mathrm{~m}$ away from trees based on quadrat plots of $1 \times 1 \mathrm{~m}^{2}$ and ratio between female and male tree of 0.46 ; and seedlings with each leaves class were considered as survival of the seeds (Table 6).

Based on the total number of seedlings grow in all plots, that was 15.4, therefore fertility of Lontar seed was the number of survivors divided by the average of seeds produced (15.4/4480), equals to $0.34 \%$. Seed dispersal for Lontar mostly due to animal dispersion (squirrel), however, this percentage is very low. In terms of plot area's fertility and plant productivity, there were only 2 of them are productive (Table 6) and produced more seedlings. This because of the environments among 6 study sites are different, as also that seed dispersal and fecundity often depend on the local environment (Schurr et al., 2008) and variation occurred between dry forest and wet forest (Howe and Kerckove,

Table 4. Calculated density of B. flabellifer using ENVI 4.5 software in Linamnutu.

\begin{tabular}{ccccc}
\hline No & Densitas (trees/hectare) & Number of pixel & Area (hectare) & Total number of trees \\
\hline 1 & 12 & 13,047 & 130.47 & 1,616 \\
2 & 28 & 12,822 & 128.22 & 3,606 \\
3 & 44 & 11,871 & 118.71 & 5,208 \\
4 & 60 & 13,630 & 136.3 & 8,125 \\
5 & 75 & 13,012 & 130.12 & 9,805 \\
6 & 91 & 12,050 & 120.50 & 10,977 \\
7 & 107 & 12,371 & 123.71 & 13,217 \\
8 & 123 & 14,430 & 144.3 & 17,689 \\
9 & 138 & 14,923 & 149.23 & 20,642 \\
10 & 154 & 11,668 & 116.68 & 17,977 \\
11 & 170 & 14,248 & 142.48 & 24,194 \\
12 & 186 & 13,354 & 133.54 & 31,187 \\
13 & 201 & 15,493 & 154.93 & 26,604 \\
14 & 217 & 12,258 & 122.58 & 36,176 \\
15 & 233 & 15,541 & 155.41 & 35,946 \\
16 & 249 & 14,464 & 144.64 & 558,138 \\
17 & 256 & 218,023 & $2,180.23$ & $\mathbf{8 4 5 , 8 8 5}$ \\
\hline
\end{tabular}

Source : Data analysis.

Table 5. Classification of area covered by Lontar in Linamnutu based on ArcGIS 9.3, and ENVI 4.5 software calculation.

\begin{tabular}{lcrrrr}
\hline Classification & $\begin{array}{c}\text { Density category } \\
\text { (tree/ha) }\end{array}$ & $\begin{array}{c}\text { Density } \\
\text { (tree/ha) }\end{array}$ & $\begin{array}{r}\text { Number of } \\
\text { tree (\%) }\end{array}$ & $\begin{array}{c}\text { Estimated } \\
\text { cover area (ha) }\end{array}$ & $\begin{array}{c}\text { Cover area } \\
(\%)\end{array}$ \\
\hline Very rare & $<70$ & 18554 & 2 & 513 & 11.86 \\
Rare & $71-130$ & 51688 & 6 & 518 & 11.97 \\
Fair & $131-180$ & 62813 & 7 & 408 & 9.43 \\
Dense & $181-250$ & 190806 & 23 & 852 & 19.67 \\
Very dense & $>251$ & 522025 & 62 & 2039 & 47.07 \\
\hline
\end{tabular}

Source : Data analysis.

Table 6. Fecundity of B. flabellifer L. in Linamnutu.

\begin{tabular}{cccccccccc}
\hline Plot & $\begin{array}{c}\text { Average } \\
\text { seeds/m }\end{array}$ & Total & Total & No of & & \multicolumn{5}{c}{ Total seedlings of different leaves classes in each plot } \\
\cline { 7 - 10 } & seeds/tree & trees & seeds & & $<4$ lvs & 4 lvs & 5 lvs & 6 lvs & 7 lvs \\
\hline 1 & 20.0 & 166 & 13 & 4796 & 40 & 0 & 1 & 0 & 1 \\
2 & 19.5 & 162 & 10 & 3600 & 10 & 2 & 1 & 0 & 1 \\
3 & 12.0 & 100 & 17 & 3778 & 1 & 0 & 3 & 0 & 0 \\
4 & 12.5 & 104 & 25 & 5778 & 1 & 0 & 1 & 4 & 6 \\
5 & 18.5 & 154 & 13 & 4449 & 3 & 1 & 1 & 0 & 0 \\
\hline Average & 16.5 & 137 & & 4480 & 11 & 0.6 & 1.4 & 0.8 & 1.6 \\
\hline
\end{tabular}

Source : Data analysis. 
1979). This means that survival of Lontar seed is still natural, and local people had not rejuvenated Lontar efficiently as also reported by Anonymous (1994). This natural survival of Lontar seed is able to be raised by giving such a moist environment to the mature seeds, this seedling culture technology should be trained to the local people (Tambunan, 2010) in order to rejuvenate Lontar orchard.

\section{CONCLUSION}

The high density and number of trees of Lontar in nature that was 195 trees per hectare, with the total trees of 845.9, and seed survivorship of $0.34 \%$, this indicates that the future prospect of Lontar sustainability is still enough for inhabitants of Linamnutu village to use Lontar for daily consumption at least for 5 years. However, in terms of future needs for economic subsistence for people, with an estimation of human population increase, this must be a local wisdom to culture the Lontar seedlings in proper way supported by an effective government policy.

\section{ACKNOWLEDGEMENT}

Author thanks to EIFI (Eastern Indonesian Field Intensive) program, a collaboration program between Faculty of Biology UGM, Satya Wacana, Undana, and Charles Darwin University Australia.

\section{REFERENCES}

Anonymous. 1994. Laporan Dinas Perkebunan Provinsi Nusa Tenggara Timur, Kupang. Anonymous. 2011. PLANTS Profile for Toddy Palm (Borassus flabellifer). USDA National Resource Conservation Service. http://plants.usda.gov/java/ profile? symbol= BOFL2. Accessed on 12 Aug 2011.

Ayarkwa, J. 1997. Potential for Utilisation of Borsassus aethiopum (Fan Palm) in Construction in Ghana. Forestry Research Institute of Ghana (FORIG) Kullasi. Ghana.

Barbour, M.G., Burk, J.H., and Pitts, W.D., 1987. Terrestrial Plant Ecology $2^{\text {nd }}$ edition. Benjamin Cummings, California. pp 51-54.

Bayton, R. P. 2007. A Revision of Borassus L. Kew Bulletin, 62(4):561-585.
Danoedoro, P. 1996. Pengolahan Citra Digital, Teori dan Aplikasinya dalam Penginderaan Jauh. Fakultas Geografi Universitas Gadjah Mada, Yogyakarta. pp 253.

Howe, H.F., and Kerckhove, G.A.V., 1979. Fecundity and Seed Dispersal of a Tropical Tree. Ecology 60(1):180-189.

Jayusman, 2010. Perkembangan Budidaya Lontar di Pulau Sawu, Nusa Tenggara Timur. Jurnal Paramita, 20(1):61-71

Morton, J.F., 1988. Notes on Distribution, Propagation, and Products of Borassus Palms (Arecaceae) Economic Botany, 42(3):420-441

Myers, B., Wurm, P., Fisher, R., Palekahelu, D., Mangimbulude, J., Liufeto, G., and Kapa, M. 2010. Laporan Teknis Lapangan EIFI tanggal 23 November - 5 Desember 2009. Sumber Makanan dan Air di Desa Linamnutu: Sebuah Penelitian Awal.

Sancayaningsih, R. P., Maharani, M.F., and Santosa, S.H.M.B. 2012. Potency of Gewang (Corypha utan Lamk.) in Linamnutu Village, Timor Tengah Selatan Regency, Nusa Tenggara Timur Province. $2^{\text {nd }}$ ISNPINSA , UNDIP October 4 th, 2012

Satomo, D.P. 2011. Angka Reproduksi Neto/Net Reproductive Rate http:// duniadinu.blogspot. com/search/label/Demografi/ Accessed on 16 Dec 2011.

Schurr., F.M., Steinitz, O., and Nathan, R., 2008. Plant Fecundity and Seed Dispersal in Spatially Heterogeneous Environment: Models, Mechanisms and Estimations. Journal of Ecology, 96(4):628-641.

Subagja, J., Djohan, T.S., Hadisusanto, S., Sancayaningsih, R. P., 2009. Petunjuk Praktikum Ekologi. Laboratorium Ekologi Fakultas Biologi UGM. Yogyakarta. pp 11.

Sudiana, D., and Diasmara, E. 2008. Analisis Indeks Vegetasi Menggunakan Data Satelit NOAA/AVHRR dan TERRA/AQUAMODIS. Seminar on Intelligent Technology and Its Applications. Surabaya.

Tambunan, P. 2010. Potensi dan Kebijakan Pengembangan Lontar untuk menambah Pendapatan Penduduk. Jurnal Analisis Kebijakan Kehutanan, 7(1):27-45.

Tarumingkeng, R. C. 1994. Dinamika Populasi, Kajian Ekologi Kualitatif. Pustaka Sinar Harapan. Jakarta. pp 56-54. 